\title{
2010 ADSA-ASAS Sectional Award
}

\section{Northeast ADSA-ASAS Distinguished Service Award}

James E. Wohlt was appointed to the Rutgers University faculty in 1978. He has published numerous scientific articles, technical abstracts, university fact-

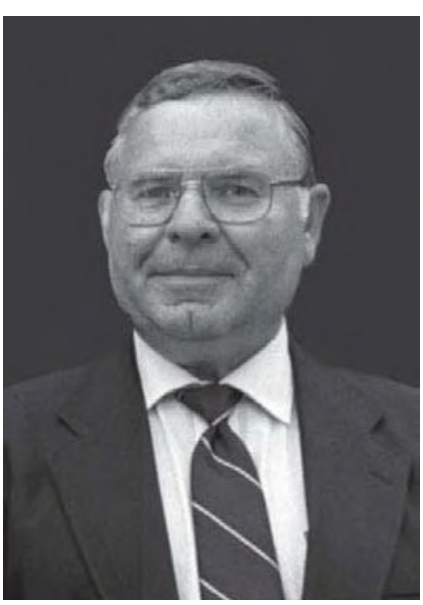

sheets, and other technical articles during his career. Jim completed some of the earliest research measuring protein solubility and requirements of amino acids for milk production. Although most of his research has been with dairy cattle, he has also conducted research with other species (sheep, swine, and horses). One of the marks of Jim's research is being attuned to the needs of New Jersey. He has studied the use of by-products (sea clam viscera, brewers/ microbrew grains, and food residuals) as animal feed, compared the value of different bedding sources, and studied the influence of basic management practices (tail-docking, handling, dehorning, identification, and transportation) on the well-being of animals. His research and scholarship has been well-recognized by his Rutgers peers, and in 1998 he received a College award for Sustained Academic and Professional Excellence. This award is given annually to a faculty member who has a history of sustained excellence.

Wohlt's passion truly lies with teaching. In the past 15 years, Wohlt has received 11 awards by his peers for teaching and advising. Twice he has been Alpha
Zeta teacher of the year, and 5 times he has received an award for outstanding advising. In 2005, he received the Land O'Lakes, Purina Feed Teaching Award in Dairy Science; this is an award of the American Dairy Science Association in recognition of outstanding ability as an undergraduate teacher. These awards have been selected by students and peers, both local and national. The breadth of his teaching skills is impressive, and he is respected for the overall excellence of his work. Jim's philosophy of teaching is hands-on. He wants students to learn thinking and reasoning skills as opposed to memorization of facts. He genuinely cares for students and doesn't expect more of them than he does of himself.

Wohlt has taught both undergraduate and graduate courses while at Rutgers, including most of the production courses, graduate ruminant nutrition, and student and honors research. More than 2,500 students have enrolled in his courses. Wohlt is the coordinator for the Agriculture Field Day livestock events. He works with student clubs, such as the Society of Animal Science and Alpha Zeta and helps the student Society of Animal Science coordinate involvement in the Northeast Animal Science Student (NESA) affiliate.

Wohlt has been undergraduate program director since 1991. In this role he coordinates course offerings and ensures that nearly 400 animal science undergraduates make progress toward their degrees. He regularly meets with parents and their high-school-age children to describe the program and often sacrifices his own personal time by meeting on evenings or weekends. He is a recruiter, and although his approach is low key, his concern for students, his commitment to animal science programs, and his genuine manner persuade many to undertake and achieve a successful animal science experience. 